PARADIGMA JURNAL KAJIAN BUDAYA Vol. 6 No. 2 (2016): 145-164

\title{
PERUBAHAN BUDAYA KERJA PERTANIAN LAHAN KERING ATONI PAH METO DI KABUPATEN TIMOR TENGAH UTARA
}

\author{
Damasius Sasi \\ Mahasiswa S2 Pascasarjana Universitas Nusa Cendana Kupang, ullan_s@ymail.com
}

DOI: $10.17510 /$ paradigma.v6i2.94

\begin{abstract}
The goal of the study is to review changes in dryland farming culture of atoni pah meto in North Center Timor District caused by global climate changes. The research method used was qualitative descriptive: the data collecting method used was interviews, observations, and the document study. Research results prove that the atoni pah meto which consists of eighteen farming rituals, five work patterns, work division between genders, and work ethos, has shifted. It is caused by the interaction of atoni pah meto with other nations, tribes, and ethnic groups, further affected by global climate changes. Climate changes have made a great impact on farmer's existence and culture. Because of that, the atoni pah meto of NCT District must open up more by accepting changes in the form of program intervention from the governmental and private institutions. It is time to leave shifting cultivation and slash and burn culture, and move to nature friendly farming technologies. Sickle culture will be offered here to replace slash and burn culture, supported by technologies, a more efficient work pattern and work division, and high work ethos, and it is expected that dryland farming of atoni pah meto will persevere.
\end{abstract}

\section{KEYWORDS}

Change; culture; atoni; pah; meto; climate; global.

\section{PENDAHULUAN}

Atoni pah meto merupakan kata majemuk yang terdiri dari atoni (dapat berarti laki-laki dan berarti juga kelompok orang/suku bangsa). Pah, berarti tempat atau wilayah. Meto, berarti kering atau daratan. Dengan demikian, atoni pah meto, adalah orang yang mendiami daratan sekaligus nama penduduk Pulau Timor bagian Barat, khususnya yang mendiami Kabupaten Timor Tengah Utara (TTU), Timor Tengah Selatan, dan sebagian Kabupaten Kupang. Bahasa yang digunakan adalah uab meto. Sebutan atoni pah meto sekaligus membedakan atoni pah meto dengan orang lain atau pendatang yang disebut kase. Nama itu menunjukkan pula bahwa atoni pah meto menggantungkan kehidupannya pada pertanian di lahan kering (berladang), atau dalam istilah lokal disebut malak. 
Secara geografis, Kabupaten TTU memiliki wilayah seluas 2.669,7 $\mathrm{km}^{2}$ atau sekitar $5,48 \%$ dari luas daratan Provinsi Nusa Tenggara Timur. Sementara itu, wilayah laut kurang lebih $950 \mathrm{~km}^{2}$ dengan panjang garis pantai kurang lebih 50 km. Secara administratif, Kabupaten TTU terdiri dari 24 kecamatan dan 193 desa/kelurahan (BPS Timor Tengah Utara 2015, 3).

Topografi Kabupaten TTU pada umumnya bergelombang dan berbukit-bukit dengan ketinggian yang bervariasi: 1) $177,60 \mathrm{Km}^{2}$ (6,63\%) memiliki ketinggian kurang dari 100 meter di atas permukaan laut (DPL); 2) $1.499,45 \mathrm{Km}^{2}(56,17 \%)$ memiliki ketinggian $100-500$ meter DPL; 3$) 993,19 \mathrm{Km}^{2}(37,20 \%)$ memiliki ketinggian lebih dari 500 meter DPL (Susandi 2014, 17).

Atoni pah meto di Kabupaten TTU, secara turun-temurun menggantungkan kehidupannya pada pertanian, terutama pertanian lahan kering, dan peternakan. Kehidupan itu sejalan dengan apa yang dikatakan Arsyad $(2010,405)$, peran sektor pertanian dalam kehidupan pembangunan ekonomi sangat penting karena sebagian besar penduduk di negara miskin menyandarkan hidupnya pada sektor itu.

Pertanian lahan kering merupakan kegiatan budi daya tanaman yang dilakukan dalam kondisi kekeringan sedang sampai berat selama sebagian besar musim tanam. Akibatnya, diperlukan teknik budi daya khusus, jenis tanaman, dan sistem usaha tani tertentu untuk memungkinkan produksi yang berkelanjutan (Benu dan Mudita 2013, 20).

Pertanian lahan kering atau berladang yang dipraktikkan atoni pah meto juga mengenal teknik tertentu dan pada akhirnya dikenal dengan budaya bertani lahan kering atoni pah meto di Kabupaten TTU. Keadaan itu juga sejalan dengan pendapat Mardimin $(2004,12)$ yang mendefinisikan, "kebudayaan adalah seluruh cara hidup manusia yang dianut bersama dalam suatu masyarakat guna mencapai taraf hidup yang lebih baik".

Budaya bertani lahan kering atoni pah meto tidaklah statis tetapi dinamis. Dinamika terjadi berkat interaksi antara atoni pah meto dan bangsa, suku bangsa, etnis, dan subetnis sehingga terjadi pertukaran budaya. Dalam dua sampai tiga dekade terakhir, pertanian lahan kering atoni pah meto terkena dampak perubahan iklim global (global climate change). Dampak perubahan iklim global yang dirasakan antara lain atoni pah meto mengalami gagal tanam dan juga gagal panen sebagai akibat hujan yang kurang atau hujan yang berlebihan. Bencana lain adalah kemarau yang berkepanjangan, serangan hama terutama belalang kumbara yang kian ganas, bencana angin puting beliung, dan bencana alam lain.

Perubahan iklim global telah menjadi isu penting dan menarik perhatian berbagai pihak, baik negarawan, akademisi, praktisi, maupun petani, nelayan, dan pedagang. Iklim menunjukkan anomali yang ditandai dengan berbagai perubahan khususnya perubahan musim yang signifikan dan berpengaruh pada kehidupan, tingkat produksi usaha tani. Perubahan iklim global ditengarai bukan lagi sekadar wacana. melainkan telah benar-benar merupakan ancaman kehidupan di planet Bumi. Kondisi yang paling dirasakan oleh manusia adalah musim yang bersifat paradoksal seperti dirasakan di Indonesia dalam beberapa dekade terakhir. Indonesia dipengaruhi iklim tropis yang mengenal dua musim, yakni musim penghujan dan musim kemarau, masing-masing selama enam bulan, tidak lagi seperti dahulu. Beberapa daerah mengalami banjir pada musim kemarau, demikian juga sebaliknya. Ancaman anomali iklim adalah gagal panen yang sudah pasti mengakibatkan gangguan stok pangan nasional dan kelaparan (Arjana 2010, 2).

Perubahan iklim global di atas mendorong atoni pah mato untuk meninggalkan ladangnya, ada yang memilih menjual lahannya untuk dijadikan tambang mangan. Ada pula untuk modal mengadu peruntungan di tanah rantau, baik di dalam negeri maupun di luar negeri sebagai tenaga kerja Indonesia (TKI) sekalipun dari aspek sumber daya manusia tidak memadai untuk bekerja di luar negeri. Kondisi itu tentu saja bertolak belakang dengan apa yang dikatakan Foni $(2002,91)$ bahwa kebun (lele) bagi atoni pah meto merupakan kampung kedua setelah kuan karena lele memberikan sejuta harapan tentang masa depan atoni. 
Perubahan iklim tidak lagi diperdebatkan keberadaannya, tetapi sudah menjadi permasalahan bersama antarkomunitas, antarinstansi, antarnegara. Bahkan sudah menjadi permasalahan global sehingga harus ditangani secara serius. Begitu banyak aspek kehidupan yang terkena dampaknya, apalagi sektor pertanian. Produktivitas dan progres sektor pertanian dipengaruhi oleh banyak faktor, terutama anomali iklim. Oleh karena itu, tidak mengherankan bahwa usaha di sektor pertanian berada pada posisi ketidakpastian (unpredictable), (Nurdin n.d.).

Dalam pandangan penulis ini, jika petani di negara maju dengan teknologi mutakhir saja masih mengeluhkan dampak perubahan iklim global, apalagi petani atoni pah meto di Kabupaten TTU yang dapat dikatakan masih sangat bergantung pada alam dan menggunakan teknologi yang sangat sederhana warisan turun-temurun. Tidaklah mengherankan tatkala kegalauan itu menjadi pokok bahasan di kala kami berdiskusi dengan petani di Kabupaten TTU.

Dari pokok pikiran diatas, penulis ini merasa terinsprasi sekaligus termotivasi untuk mengkaji perubahan budaya bertani lahan kering atoni pah meto yang terkena imbas perubahan iklim global. Dampaknya terasa dalam budaya bertani lahan kering atoni pah meto yang berupa ritus pertanian, pola kerja, pembagian kerja, dan etos kerja sebagaimana teramati dewasa ini. Oleh karena itu, dirumuskan pertanyaaan penelitian: (1) faktor apakah yang menyebabkan perubahan budaya pertanian lahan kering atoni pah meto; (2) bagaimana perubahan pelaksanaan ritus pertanian lahan kering pada atoni pah meto; (3) bagaimana perubahan pelaksanaan pola kerja atoni pah meto; (4) bagaimana perubahan pembagian kerja atoni pah meto; (5) bagaimana perubahan etos kerja atoni pah meto, dan (6) bagaimana dampak perubahan iklim global pada perubahan budaya bertani lahan kering atoni pah meto? Tujuan penelitian ini adalah untuk menjelaskan: (1) faktor perubahan budaya pertanian lahan kering; (2) perubahan pelaksanaan ritus pertanian lahan kering; (3) perubahan pelaksanaan pola kerja; (4) perubahan pembagian kerja atoni pah meto; (5) perubahan etos kerja atoni pah meto, dan (6) apa perubahan iklim global pada budaya bertani lahan kering atoni pah meto.

Permasalahan penelitian di atas dikaji dengan metode penelitian deskriptif kualitatif: dengan teknik pengumpulan data wawancara dan observasi diperoleh data primer dan dengan studi dokumen diperoleh data sekunder.

\section{Faktor perubahan budaya pertanian lahan kering atoni ah meto}

Seiring dengan perubahan pada aspek waktu, aspek pengetahuan, kebudayaan yang dimiliki oleh manusia juga mengalami perubahan, termasuk di dalamnya kebudayaan atoni pah meto. Faktor penyebab sebagai berikut.

a. Perubahan pengetahuan atoni pah meto. Pengetahuan itu adalah hasil interaksi dengan suku lain, misalnya orang dari Belu (Belus), Rote (Lotes), Sabu (Sabus), orang Tionghoa (kase/kaes sines) serta orang Eropa (kaselkaes Balana).

b. Kebijakan dan peraturan yang dikeluarkan oleh bangsa Portugis dan bangsa Belanda. Untuk kepentingan perdagangan, dikeluarkan kebijakan pemerintah kolonial untuk memasukkan kuda dari Sumba guna kepentingan pengangkutan kayu cendana, lilin, dan madu yang merupakan komoditas khas dari Pulau Timor. Sementara itu, sapi bali didatangkan ke Pulau Timor dengan pertimbangan padang sabana yang cocok untuk pengembangbiakan sapi Bali dan juga untuk ekspor ke Pulau Jawa dan daerah lain di wilayah Indonesia. Widyatmika $(2008,323)$ mengatakan bahwa salah satu awal perubahan di bidang peternakan yang memberi warna dalam kehidupan ekonomi masyarakat adalah pembangunan ternak sapi pada 1912 oleh pemerintah Hindia Belanda. Kemudian, Fox (1977) yang dikutip Widyatmika $(2008,331)$, menyatakan bahwa perubahan pola 
konsumsi atoni pah meto juga terjadi sejak zaman penjajahan Belanda. Lewat VOC, Belanda memasukkan tanaman jagung pada 1672 untuk memperbaiki makanan penduduk di Pulau Timor.

c. Bangsa Eropa juga menyebarluaskan agama. Agama Katolik dibawa dan disebarkan oleh misionaris Portugis dan agama Kristen Protestan dibawa dan disebarkan oleh zending dari Belanda. Menurut Widiyatmika (2007, 173-175) penyebaran Agama Katolik di Nusa Tenggara Timur dirintis oleh para padri dan pedagang. Portugis mulai mendarat di Timor pada 8 Juli 1514. Dengan tekanan kuat agama yang dianut, dalam pandangan penulis ini, ritus bertani dan berbagai aktivitas yang dianggap berhala ditinggalkan dan digantikan dengan tata liturgi tiap-tiap agama.

d. Politik etis yang dilaksanakan oleh pemerintah Belanda di Hindia Belanda, salah satunya adalah pendidikan. Menurut Widiyatmika (2007, 180-184), pendirian lembaga pendidikan formal di Nusa Tenggara Timur tidak dapat dilepaskan dari kolonialisme Barat dalam hal ini Portugis dan Belanda. Pelajaran yang diberikan di sekolah adalah membaca, berhitung, menulis, ilmu bumi, sejarah Bibel. dan nyanyian gregorian. Di luar jam pelajaran, para siswa diajari berkebun. Di TTU pada 1912-1928 dibuka 14 sekolah baru, antara lain di Noetoko pada 1921, Kefa dan Naknono pada 1916, Oelolok dan Sufa pada 1918, Noemuti dan Aplal pada 1920. Kebijakan itu memberi kesempatan kepada putra/i atoni pah meto, khususnya dari golongan bangsawan dan mampu, untuk mengenyam pendidikan.

e. Kemerdekaan bangsa Indonesia yang diproklamirkan pada 17 Agustus 1945 menyebabkan bangsa Indonesia bebas menentukan nasibnya. Berbagai upaya terus dilakukan untuk memperbaiki kehidupan bangsa Indonesia.

f. Anak-anak atoni pah meto dewasa ini, dengan dunia yang lebih terbuka, mendapat pendidikan yang memadai, dan terkena derasnya arus informasi. Akibatnya, teknologi dan cara bertani yang dianggap tidak sesuai mulai ditinggalkan.

g. Sistem pemerintahan tradisional sudah lama ditinggalkan sehingga keberadaan individu yang memiliki pengetahuan tentang tata urutan ataupun tata upacara adat yang diwariskan secara turun-temurun disesuaikan dengan situasi dan kondisi aktual.

h. Banyak putra/i atoni pah meto sudah bekerja di sektor formal (PNS, TNI, Polri) dan nonformal (tukang kayu, tukang batu, buruh bangunan, tukang ojek, pembantu rumah tangga, dan lainnya) sehingga bertani bukan lagi pekerjaan utama.

\section{Perubahan pelaksanaan ritus pertanian lahan kering atoni ah meto}

Nordholt (1971, 53-91) mengatakan bahwa dalam pertanian lahan kering atoni pah meto TTU di wilayah Maubesi, terdapat empat belas ritus, yakni (a) memilih sebidang tanah; (b) meminta izin; (c) mengasah parang; (d) menebang pohon; (e) membakar kebun baru; (f) memadamkan obor bambu; (g) membendung erosi; (h) menghindarikemarau panjang dan kegagalan panen; (i) membayar tobe; (j) menjaga tanaman muda; (k) memetik jagung pertama; (I) memanen padi; (m) memanen jagung; (n) kembali ke kampung.

Pada 2001, Foni mengadakan penelitian mengenai budaya pertanian atoni pah meto, suatu studi siklus ritus kegiatan pertanian lahan kering atoni pah meto Tunbaba di TTU. Temuan penelitiannya membuktikan bahwa dalam ritus pertanian atoni pah meto Tunbaba, terdapat delapan belas siklus ritus pertanian lahan kering atoni pah meto Tunbaba, yaitu (a) membuka lahan baru (tafek nono hau ana); (b) membakar tebasan (tait nuta ma nopo); (c) mendinginkan lahan yang telah dibakar (tsifo nopo); (d) memilih bibit dan menanam (tsimo suan); (e) mendatangkan hujan (toit ulan); (f) membersihkan lahan (tofa lele); (g) membendung 
aliran air (eka hoe); (h) memanen hasil perdana (ta'non); (i) menjaga hama burung (tiut kolo); (j) menghalau hujan (tkau ulan); (k) memanen padi (houn ane); (I) memilah bulir padi (hail ane), (m) memanen jagung (seke pena); (n) mengikat jagung (kaibu pena); (o) mengundang roh makanan ke kampung (nau bolaif); (p) menyimpan hasil panen (tahik mnahat); (q) menempatkan kembali roh makanan dalam rumah (seve so'e); (r) mempersembahan hasil panen sebagai sesajian pada uis pah (tatam pen tauf) (Foni, 2002, 110-194). Dalam pandangan penulis ini, kondisi yang dikemukakan oleh kedua peneliti terdahulu tidaklah statis tetapi dinamis dan berhubungan dengan uraian mengenai faktor penyebab perubahan budaya pertanian lahan kering atoni pah meto di atas. Perubahan yang ditemukan oleh penulis ini sesuai dengan hasil penelitian antara lain yang berikut.

a. Sistem pemerintahan tradisional sudah lama dihapus, yang ditandai dengan pemberlakuan Undang-undang Nomor 64 Tahun 1958 (Lembaran Negara No 115 tahun 1958): Provinsi Sunda kecil dipecah menjadi daerah Swatantra Tingkat I Bali, Nusa Tenggara Barat dan Nusa Tenggara Timur (NTT). Kemudian, berdasarkan Undang-Undang Nomor 69 Tahun 1958 Tentang Pembentukan Daerah-Daerah Tingkat II, daerah Swatantra Tingkat I NTT dibagi menjadi 12 daerah Swatantra Tingkat II, termasuk Daerah Tingkat II TTU. Dampaknya adalah pemerintahan adat dengan tokohtokoh yang memiliki otoritas seperti tobe (tokoh yang memiliki otoritas dalam bidang pertanahan), mafefa/malasi (juru bicara adat), tidak lagi memiliki peran yang nyata sebagaimana pada masa pemerintahan tradisional.

b. Kelengkapan upacara seperti hewan kurban, pada waktu lalu wajib hukumnya. Hewan yang disembelih adalah ayam kampung dan babi kampung dengan bulu atau warna yang juga ditentukan. Namun, sejak tahun 2005, seiring dengan perkembangan pesat peternakan ayam broiler, populasi ayam kampung dan babi kampung semakin kecil karena serangan penyakit serta petani yang membudidayakan juga semakin sedikit. Dibutuhkan waktu lebih panjang untuk memelihara ayam kampung, sementara harganya lebih mahal, dagingnya juga lebih sedikit. Akibatnya, sering kali dijumpai hewan untuk korban adalah ayam broiler (warga sering menyebutnya ayam potong) yang bulunya berwarna putih atau ayam petelur yang sudah tidak produktif lagi karena harganya lebih murah serta dagingnya lebih banyak. Babi yang disembelih juga tidak lagi babi kampung tetapi babi pedaging. Alasannya, memelihara babi kampung membutuhkan waktu yang lebih panjang, biaya untuk memeliharanya juga lebih besar karena babi kampung rentan terhadap penyakit.

c. Perlengkapan kerja untuk tafek nono hau ana, yang jarang ditemukan untuk digunakan saat membuka lahan baru, adalah kapak (fani). Penyebabnya, tidak ada lagi pepohonan besar yang harus ditebang. Penulis ini memandang bahwa keadaan itu positif, artinya dengan makin jarang, bahkan tidak sama sekali, menggunakan kapak (fani), peluang dan budaya tebas bakar akan makin berkurang, bahkan hilang. Oleh karena itu, penulis ini menyarankan penggunaan arit pada atoni pah meto di dalam bertani lahan kering. Arit bukanlah teknologi baru sama sekali bagi atoni pah meto di Kabupaten TTU, tetapi belum membudaya dan digunakan secara luas. Arit biasanya hanya digunakan oleh peternak sapi untuk memotong rumput untuk pakan ternak.

d. Keadaan iklim yang tidak menentu selama dekade terakhir. Menurut pandangan informan yang ditemui, atoni pah meto mulai menyadari efektivitas dan efisiensi waktu. Daripada membuang waktu untuk ritual bersama, mengeluarkan sejumlah biaya, setiap orang memilih untuk berdoa dan melakukan sendiri upacara. Dengan demikian, mereka mempunyai waktu cukup untuk mengolah lahannya. Penulis ini memandang bahwa sangat penting dibangun pengetahuan atoni pah meto, kesadaran akan efektivitas dan efisiensi dalam segala hal. Dengan demikian, atoni pah meto tidak 
lagi menjadi petani tradisional tetapi petani modern, baik dari aspek teknologi maupun aspek pola pikir.

\section{Perubahan pelaksanaan pola kerja atoni pah meto}

Pola kerja yang dimaksudkan dalam penelitian ini adalah pengerahan tenaga kerja dalam pertanian lahan kering, khusunya pada atoni pah meto di Kabupaten TTU. Mulai dari membuka lahan sampai dengan panen, sebagian besar tenaga kerja berasal dari keluarga petani sendiri. Atoni pah meto TTU di dalam aktivitas bertani lahan kering mengenal pembagian kerja sebagai berikut.

\section{a. Bekerja untuk orang dengan status sosial lebih tinggi (meup tauis/nauis)}

Pola kerja ini wajib dan dilakukan untuk seseorang yang berstatus sosial lebih tinggi. Pada masa pemerintahan adat/ tradisional masih berlaku, pola kerja itu sangat ketat diterapkan, baik untuk kepentingan raja (usif) maupun kepentingan penjajah. Melaksanakan pekerjaan dengan pola ini bersifat sukarela, tanpa upah, maka keperluan makan dan lainnya disiapkan sendiri. Perubahan pada pola kerja ini sebagai berikut.

1. Pemerintahan adat sudah tidak berjalan lagi, dan tidak lagi ada penjajahan sehingga tidak ada lagi kebun/lahan milik usif, tobe, amaf yang wajib diolah dengan melibatkan rakyat (tob). Secara positif, penulis ini memandang bahwa hal ini merupakan suatu kemajuan yang patut dipelihara, mengingat bahwa pada waktu sistem pemerintahan tradisional dan pada zaman penjajahan praktik pola kerja ini sering menyebabkan rakyat kecil menderita akibat perlakuan yang sewenang-wenang.

2. Kalaupun keluarga bangsawan (pemangku adat) ingin menggunakan jasa orang dalam mengolah lahan pertanian miliknya, para amaf dan tokoh adat lain akan mengomunkasikan hal ini kepada warga dan sifatnya tidak memaksa. Sisi baik yang dapat kita lihat adalah penghargaan terhadap harkat dan martabat manusia sekalipun dirinya adalah anggota masyarakat bawah.

\section{b. Bekerja sama sebagai pertukaran kerja (meup/mepu tanonob)}

Pola kerja ini dilaksanakan oleh dua orang atau lebih yang memiliki kebun/lahan pada hamparan yang sama. Perubahan pada pola kerja ini, sudah jarang atau tidak lagi dipraktikkan sebagaimana pada era pemerintahan adat. Alasannya, dewasa ini setiap orang merasa wajib bertanggung jawab atas lahannya, serta merasa membuang-buang waktu dengan mengontrol atau membantu mengerjakan lahan milik sesamanya. Selain itu, terkadang timbul salah paham di antara petani sehingga terjadi semacam trauma pada atoni pah meto: niat baik terkadang disalah artikan atau salah dipahami, bahwa orang yang membantu memiliki niat yang tidak baik terhadap sesama yang kebunnya kebetulan berdekatan. Pada bagian ini kita melihat pergeseran nilai-nilai yang cukup besar, artinya rasa setia kawan hilang dan rasa persaudaraan memudar.

\section{c. Bekerja dengan saling mengundang (meup taoen)}

Pola kerja ini dipraktikkan bersifat sukarela tanpa unsur paksaan. Biasanya seseorang yang merasa memiliki keterbatasan tenaga akan mengundang tetangga, saudara dan saudarinya untuk membantu di dalam mengolah lahannya. Tujuannya supaya pekerjaan yang berat dapat diringankan, serta hasilnya dapat dinikmati bersama. Perubahan yang terjadi dalam pola kerja ini adalah:

1. Di dalam mengundang sesama yang tempat tinggalnya berjauhan, ataupun untuk efektivitas sekalipun dalam jarak dekat tidak lagi hanya menggunakan media sirih pinang (puah manus) atau sopi (minuman lokal beralkohol), melainkan menggunakan media komunikasi ponsel; dan 
2. undangan untuk bekerja ini seringkali tidak diindahkan, bukan karena tidak mau menghargai namun karena masing-masing orang harus bertanggung jawab atas lahannya sendiri, mengingat terbatasnya tenaga kerja yang dimiliki.

Jika kita mengkaji keadaan tersebut, sebenarnya media komunikasi ponsel sangatlah baik karena sangat efektif dan efisien. Namun, pergeseran media komunikasi seperti sirih pinang memberi kesan ada sesuatu yang hilang pada atoni pah meto, yakni kebiasaan saling mengunjungi dan melihat keberadaan sanak famili secara bertatap muka, untuk membangun kehangatan. Dampak lebih luas adalah tidak saling mengenal sesama saudara sehingga tidak jarang menimbulkan persoalan sosial seperti tawuran pemuda antarkampung, dan ketika sudah diupayakan penyelesainnya lewat jalur mediasi atau hukum. Terkadang dijumpai hal yang unik, misalnya mereka yang terlibat tawuran barulah saling mengenal dan ternyata mereka adalah saudara setelah saling mencari tahu asal kampung, marga (fam) dan unsur-unsur kedekatan emosional lain.

\section{d. Bekerja dengan menerima upah (meup/mepu tseba)}

Pola kerja ini dipraktikkan oleh atoni pah meto di dalam mengolah lahannya karena merasa memiliki tenaga terbatas. Atoni akan mengajak beberapa orang untuk membantu dirinya bekerja dengan upah yang disepakati. Sampai akhir dekade 1990, upahnya adalah sebagian hasil panen yang berupa jagung atau padi.

Perubahan yang terjadi dewasa ini adalah tidak lagi dikenal pembagian hasil, diganti dengan pemberian upah berupa sejumlah uang yang sudah disepakati bersama antara pemberi kerja dan pekerja. Sistem pengupahan dengan sejumlah uang berjalan sejak 2000. Upah yang diterima juga mengalami kenaikan setiap tahun, rata-rata upah yang berlaku, saat diadakan penelitian ini, adalah 30.000-40.000 rupiah untuk sehari bekerja, berlaku merata untuk laki-laki dan perempuan serta merata untuk semua jenis pekerjaan (lihat 18 ritus bertani lahan kering pada bagian terdahulu). Pola kerja itu, sesuai dengan pengamatan peneliti ini, merupakan pola yang cukup lazim dipraktikkan dewasa ini oleh atoni pah meto. Dalam kondisi itu, mereka yang memiliki cukup modal serta didukung oleh iklim yang baik, tentu saja panenannya akan berlimpah, sementara petani yang memiliki keterbatasan modal, ditambah dengan kondisi iklim yang tidak menentu, serta teknologi yang terbatas, tentu saja memperoleh hasil yang juga terbatas.

\section{e. Bekerja sendiri (meupkuk)}

Pola kerja ini dipraktikkan karena atoni pah meto memandang bahwa dirinya beserta anggota keluarga inti harus menjadi ujung tombak (tu'in) sebelum mengundang orang lain untuk membantunya baik secara sukarela maupun diupah, atau dengan kata lain mandiri. Pola kerja itu paling dominan ketika penelitian ini diadakan. Satu keluarga yang terdiri dari suami, istri, dan anak, serta anggota lain yang serumah bersamasama mengolah lahan yang dimiliki sampai dengan masa panen.

Perubahan yang terjadi adalah, untuk mendapatkan hasil yang bagus dan mencukupi kebutuhan keluarga selama satu tahun, dibutuhkan tenaga kerja yang cukup, dukungan iklim, dan juga teknologi yang memadai. Namun, selama dua sampai tiga dekade terakhir kondisi iklim dirasakan tidak menentu sehingga peneliti ini mendapati tidak jarang petani yang berusia di atas 50 tahun, baik ia suami maupun istri mengolah sendiri lahan yang dimiliki. Sementara itu, anaknya ada yang masih berusia sekolah, atau tidak lagi bersekolah di jenjang pendidikan tertentu sehingga memutuskan untuk merantau dan mencari peruntungan yang lebih baik di tanah rantau. Ada semacam pandangan yaitu bekerja sebagai petani (meup meto) sudah tidak lagi memenuhi harapan dan tidak lagi sesuai dengan kekinian. 


\section{Perubahan pembagian kerja atoni pah meto}

Pembagian kerja pada atoni pah meto di Kabupaten TTU merupakan perwujudan peran individu sebagaimana dikatakan oleh Soekanto $(2012,213)$ : peran atau role merupakan aspek dinamis dalam suatu kehidupan. Apabila seorang melakukan hak dan kewajibannya sesuai dengan kedudukannya, dia menjalankan suatu peran.

Pembagian kerja dimaksud adalah pembagian peran untuk pekerjaan laki-laki dewasa, pekerjaan perempuan dewasa, pekerjaan anak-anak baik laki-laki maupun perempuan, serta pekerjaan lanjut usia. Pembagian kerja ini sangat penting di dalam tahapan mengolah lahan yang dimiliki atoni pah meto. Tujuannya untuk mengatasi tantangan berupa kondisi alam, keterbatasan teknologi serta tenaga kerja.

Perubahan yang terjadi adalah perempuan dan anak-anak tidak lagi berperan sebatas pelengkap, tetapi merupakan aktor utama. Perempuan terlibat sejak perencanaan, pelaksanaan, hingga akhir tahapan kerja bertani lahan kering pada atoni pah meto TTU. Begitu pula anak-anak, baik laki-laki maupun perempuan. Di sini kita melihat sisi positif, artinya kesadaran akan kesetaraan gender tumbuh perlahana-lahan dan berkembang pada atoni pah meto.

\section{Perubahan etos kerja atoni pah meto}

Berdasarkan petikan wawancara, etos kerja atoni pah meto dilandasi oleh filosofi yang hidup dan berkembang dalam atoni pah meto TTU dan berlaku dalam semua aktivitas kehidupan. Filosofi hidup atoni pah meto TTU yang berlaku dan menjadi pegangan dalam aktivitas bertani lahan kering antara lain yang berikut.

\section{a. Tmeup Tabua Nekaf Mese Ansaof Mese}

Tmeup tabua nekaf mese ansaof mese, secara harfiah berarti bekerja bersama, sehati sepikiran. Bekerja bersama bagi atoni pah meto dapat dipandang sebagai bentuk transformasi mental kebersamaan yang berakar dalam atoni pah meto.

Seiring dengan perubahan zaman, dewasa ini filosofi yang kemudian menjadi etos di dalam bekerja dan aspek kehidupan lain perlahan-lahan memudar. Penyebabnya adalah faham individualis pada atoni pah meto yang entah disadari atau tidak disadari tetapi dipraktikkan. Keadaan itu tampak begitu nyata ketika peneliti ini ke ladang milik patani atoni pah meto. Peneliti ini mendapati hanya sepasang suami-istri yang bekerja di ladang mereka untuk mengurusi dan merawat tanaman yang ada. Kalaupun dalam jumlah yang lebih besar, itu adalah adalah orang yang membantu dengan diberi upah. Sebagaimana uraian di bagian terdahulu, hilangya spirit nekaf mesa ansaof mese berdampak pada sikap menutup diri, apatis melihat keadaan di sekitarnya. Oleh sebab itu, lewat para tokoh, seperti kepala suku (amaf) di setiap klen (fam/ume fam), lewat acara adat atau acara lain, mental mereka perlu direvitalisasi.

\section{b. Fani Benas Naik lke Sute N'keo}

Filosofi fani benas na'ik ike sute n'keo secara harfiah berarti parang dan kapak yang tajam, kayu bulat panjang pemutar benang berputar lincah di atas piring kecil. Parang dan kapak merupakan dua perlengkapan yang secara turun-temurun digunakan oleh kaum laki-laki atoni pah meto untuk mengolah lahan pertanian yang dimiliki dan juga untuk aktivitas lain, baik untuk kepentingan sendiri maupun untuk umum (lihat pola kerja atoni pah meto). Tentu, selain kapak dan parang, atoni pah meto juga memiliki perlengkapan lain untuk mengolah ladang, misalnya linggis/besi gali (pali/kenkanu/tofa naek, suak), yang digunakan untuk membuat lubang dan membalik tanah. 
Filosofi fani benas naik ike sute n'keo pada masa lalu, adalah bahwa seorang laki-laki atoni pah meto dianggap layak berumah tangga apabila sudah memiliki sebilah parang dan kapak, serta sudah mampu mengasahnya sampai tajam dan sudah mampu menggunakan perlengkapan itu untuk mengerjakan kebun.

Sebagiamana laki-laki, seorang perempuan dewasa dalam atoni pah meto dianggap dan dikatakan pantas menikah/berumah tangga apabila sudah mampu memintal benang dan menenun selembar kain (tais dan bête). Aturan itu dipegang teguh baik oleh laki-laki maupun perempuan. Apabila sudah memasuki masa akil balik, setiap individu akan berusaha menunjukkan eksistensinya dengan bekerja baik laki-laki di kebun maupun perempuan yang menenun. Dalam kenyataan, rata-rata perempuan di Kabupaten TTU yang berusia di bawah 40 tahun sudah tidak tahu atau memiliki kemampuan menenun. Keadaan itu tentu berdampak pada keberadaan bête (kain untuk laki-laki), tais (kain untuk perempuan) yang juga menjadi salah satu ciri khas atoni pah meto. Bête dan tais sudah digantikan posisinya oleh celana jeans, legging, dan berbagai busana modern lain. Semua itu tentu berasal dari satu pola pewarisan dan transfer pengetahuan yang tidak berjalan dengan baik. Maka diharapkan peran lembaga pendidikan, baik pendidikan dasar maupun menengah, untuk menghidupkan kembali tradisi itu lewat muatan lokal.

Berangkat dari paparan singkat tentang filosofi fani benas na'ik ike sute n'keo di atas, dapat dikatakan bahwa atoni pah meto TTU memiliki etika, nilai-nilai etis yang dikaitkan dengan etos kerja. Misalnya rajin bekerja, berdisiplin tinggi, menahan diri, ulet, tekun dan nilai-nilai etika lain yang dapat ditemukan pada masyarakat dan bangsa lain. Dewasa ini, jika dicermati, terjadi pergeseran pengetahuan, pemahaman, dan praktik filosofi pada muda-mudi atoni pah meto. Oleh sebab itu, tidak jarang kita temukan pernikahan usia dini, padahal pasangan belum siap berumah tangga dengan tanggung jawab yang harus mereka emban.

\section{c. Meup On Ate Tah On Usif}

Secara harfiah filosofi meup on ate tah on usif pada atoni pah TTU berarti bekerja seperi hamba dan makan seperti raja. Filosofi itu berlaku tidak saja dalam aktivitas bertani lahan kering dengan 18 tahapan kerja yang harus dilalui, tetapi juga dalam aktivitas sosial lain. Dari filosofi itu pula terkandung makna atoni pah meto, baik laki-laki maupun perempuan, tua maupun muda, dituntut untuk bekerja keras, memanfaatkan teknologi yang dimiliki, menyatu dan menaklukkan berbagai tantangan alam, memanfaatkan segenap sumber daya.

Dalam dekade terakhir ternyata bahwa tidak jarang terdengar baik dari mulut ke mulut, maupun pemberitaan media massa cetak dan elektronik bahwa di Kabupaten TTU terjadi kasus pencurian ternak, perambahan hutan, korupsi dalam instansi pemerintahan, perdagangan manusia, dan sederet persoalan sosial lain. Itu menunjukkan bahwa filosofi hidup atoni pah meto, sebagaimana diungkapkan di atas atau juga yang belum diungkapkan dalam tulisan ini, mulai tergerus seiring dengan perubahan zaman. Itu terjadi karena perlahan-lahan faham serba instan juga mulai merasuki generasi muda di TTU. Tanpa kerja keras mau memperoleh hasil besar.

\section{d. Dampak perubahan iklim global pada budaya bertani lahan kering atoni pah meto}

Berpijak pada data dari Stasiusn Klimatologi Lasiana dan hasil wawancara dengan petani lahan kering atoni pah meto TTU, dapat dikatakan bahwa perubahan iklim global berdampak cukup serius pada kehidupan petani lahan kering atoni pah meto di Kabupaten TTU. Itu terlihat dari beberapa indikator, seperti curah hujan yang rendah, jumlah hari hujan yang sangat singkat, awal musim hujan yang cenderung mundur, musim kemarau yang semakin panjang, periode musim hujan semakin pendek, periode musim kemarau semakin panjang, sifat musim hujan cenderung di bawah normal, sifat musim kemarau cenderung semakin kering.

Atoni pah meto di Kabupaten TTU sebagai pelaku aktivitas bertani lahan kering juga merasakan kondisi itu, mereka mencoba membandingkan keadaannya dengan kondisi dua atau tiga dasawarsa yang 
lalu. Petani sudah menyiapkan ladang dan mulai menanami ladang dengan berbagai jenis tanaman pangan. Namun, ketika tanaman membutuhkan air yang cukup untuk bertumbuh, justru tidak hujan tidak kunjung turun atau turun tetapi dalam curah terbatas. Akibatnya, tanaman rusak bahkan sebelum tumbuh, atau tumbuh tetapi tidak berkembang dengan baik sehingga atoni pah meto tidak saja mengalami gagal panen, tetapi juga mengalami gagal tanam. Kondisi perubahan iklim itu menyebabkan petani mulai kehilangan harapan.

Atoni pah meto rela menjual lahan miliknya dan cenderung melakukan urbanisasi seperti ke Kota Kupang untuk mengadu peruntungan yang lebih baik. Bermigrasi tentu saja tidak dapat dikatakan salah atau tabu, tetapi yang menjadi persoalan adalah keterbatasan tenaga yang potensial dan produktif sehingga tidak mengherankan bahwa begitu banyak hamparan lahan tidur atau tidak produktif. Kondisi perubahan iklim global ini harus disadari bahwa salah satu tahap kerja atoni pah meto, yakni membakar tebasan mempunyai andil cukup besar dalam pemenasan global. Oleh karena itu, tebas bakar ini seharusnya sudah ditinggalkan dengan cara alih teknologi yang lebih ramah lingkungan.

\section{PENUTUP}

Harus diakui bahwa perubahan iklim global dengan indikator-indikatornya tidak terjadi begitu saja, tetapi semua ini merupakan hubungan sebab akibat. Karena kebutuhan manusia yang tak terbatas berdampak pada eksplorasi dan eksploitasi sumber daya alam yang tidak terkontrol.

Secara turun-temurun atoni pah meto sebenarnya mewarisi pengetahuan bahwa iklim ini sebenarnya berperan penting dalam keberhasilan aktivitas pertaniaan. Sayangnya kemampaun dan pengetahuan ini cenderung diabaikan. Oleh karena itu, penyesuaian penting dilakukan, misalnya 1) menghemat penggunaan air, 2) melakukan konservasi lahan, dan 3) lahan pertanian yang dekat sumber mata air sebaiknya tidak diolah untuk tanaman pangan, tetapi ditanami tanaman umur panjang yang tidak rakus air dan juga mampu menyimpan air.

Budaya ladang berpindah dan tebas bakar sudah saatnya ditinggalkan dan beralih ke penggunaan teknologi pertanian yang ramah lingkungan, di sini ditawarkan budaya arit (sabit) guna menghilangkan budaya tebas bakar, dengan adaptasi teknologi didukung dengan pola kerja, pembagian kerja dan etos kerja yang tinggi, diharapkan pertanian lahan kering atoni pah meto tetap eksis.

\section{Daftar Referensi}

Arjana, I Gusti Bagus. 2010. "Iklim Global dan Dampak Geografis di Indonesia". Prosiding SeminarPerubahan Iklim di Indonesia, Mitigasi dan Strategi Adaptasi dari Tinjauan Multi Disiplin, ed. Sudibyakto, Diah R. Hizbaron dan Raditya Jati. Yogyakarta: Sekolah Pascasarjana UGM.

Arsyad, Lincolin. 2010. Ekonomi Pembangunan. Yogyakarta: UPP STIM YKPN.

Benu, Fred. dan I.W. Mudita. 2013. Revisitasi lahan kering: diskusi ringan seputar lahan kering dan pertanian lahan kering. Jakarta: JP II Publishing House.

BPS Kabupaten Timor Tengah Utara. 2015. Timor Tengah Utara dalam Angka. Kefamenanu: Timor Tengah Utara.

Foni, Wilhelmus. 2002. Budaya Pertanian Atoni Pah Meto, Suatu Studi Siklus Ritus Kegiatan Pertanian Lahan Kering Atoni Pah Meto Tunbaba di Timor Tengah Utara, Nusa Tenggara Timur. Tesis Magister Studi Pembangunan Universitas Kristen Satya Wacana Salatiga.

Mardimin, Johanes, 2004. Jangan Tangisi Tradisi, Transformasi Budaya Menuju Masyarakat Indonesia Modern. Yogyakarta: Kanisius. 
Moleong, J. Lexy. 2014. Metodologi Penelitian Kualitatif. Bandung: Remaja Rosda Karya.

Nordholt, Schulte H.G. 1971. The Political System of the Atoni of Timor. Diterjemahkan oleh M. J. L. van Yperen. The Hague: Martinus Nijhoff.

Nurdin. n.d. Antisipasi Perubahan Iklim untuk Keberlanjutan Ketahanan Pangan. http://ung.ac.id.antisipasiperubahan-kklim-untuk-keberlanjutan-ketahanan-pangan.pdf (diakses 13-03-2105 23.47 wita).

Soekanto, Soerjono dan Budi Sulistyowati, ed. 2012. Sosiologi: Suatu Pengantar. Jakarta: Raja Grafindo Persada.

Susandi, Armi. 2014. Update Model Pengembangan Curah Hujan Untuk Menentukan Masa Tanam Pertanian dan Potensi Bencana dan Penyakit Terkait Iklim di Kabupaten Timor Tengah Utara Provinsi Nusa Tenggara Timur. Laporan Penelitian, Kefamenanu: Yayasan Mitra Tani Mandiri.

Widiyatmika, Munandjar. 2007. Kapita Selekta Muatan Lokal Nusa Tenggara Timur. Kupang: Pusat Pengembangan Madrasah NTT.

. 2008. Kebudayaan Masyarakat di Bumi Cendana. Kupang: Pusat Pengembangan Madrasah NTT. 


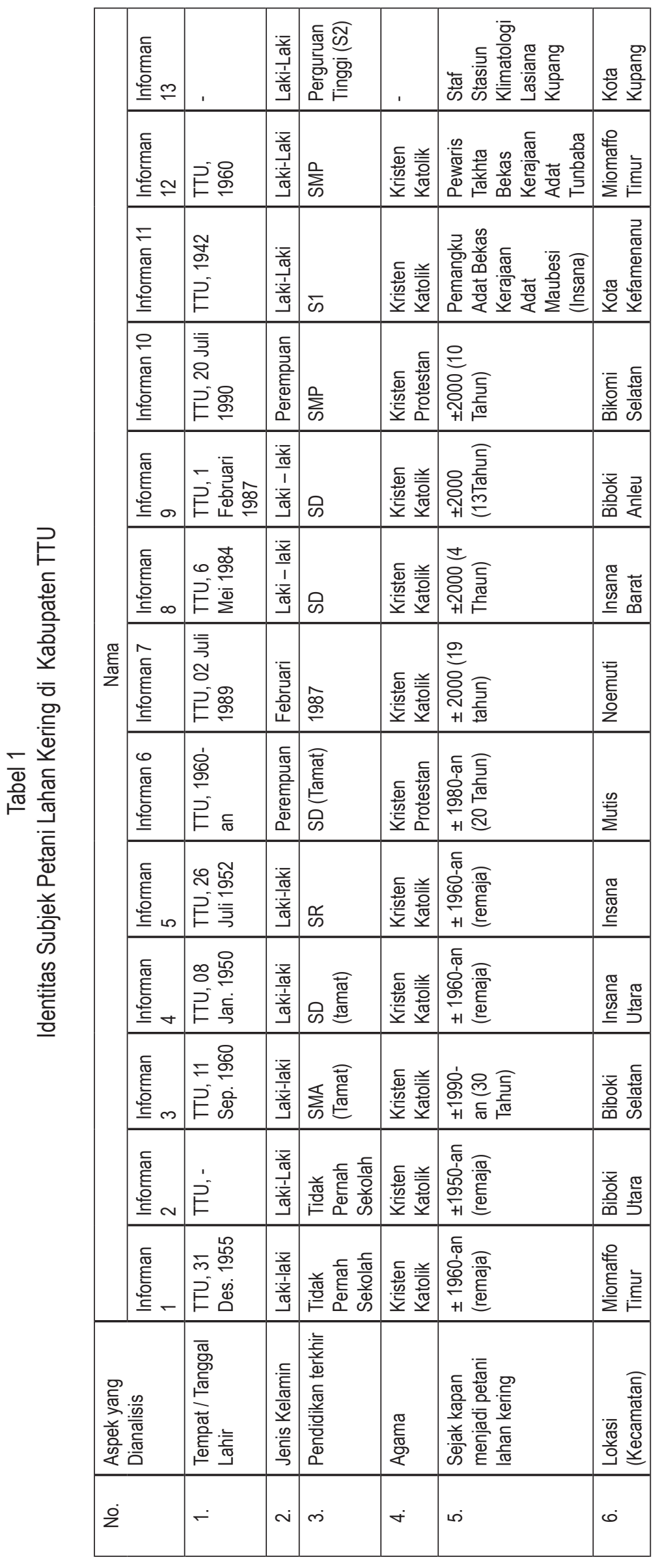




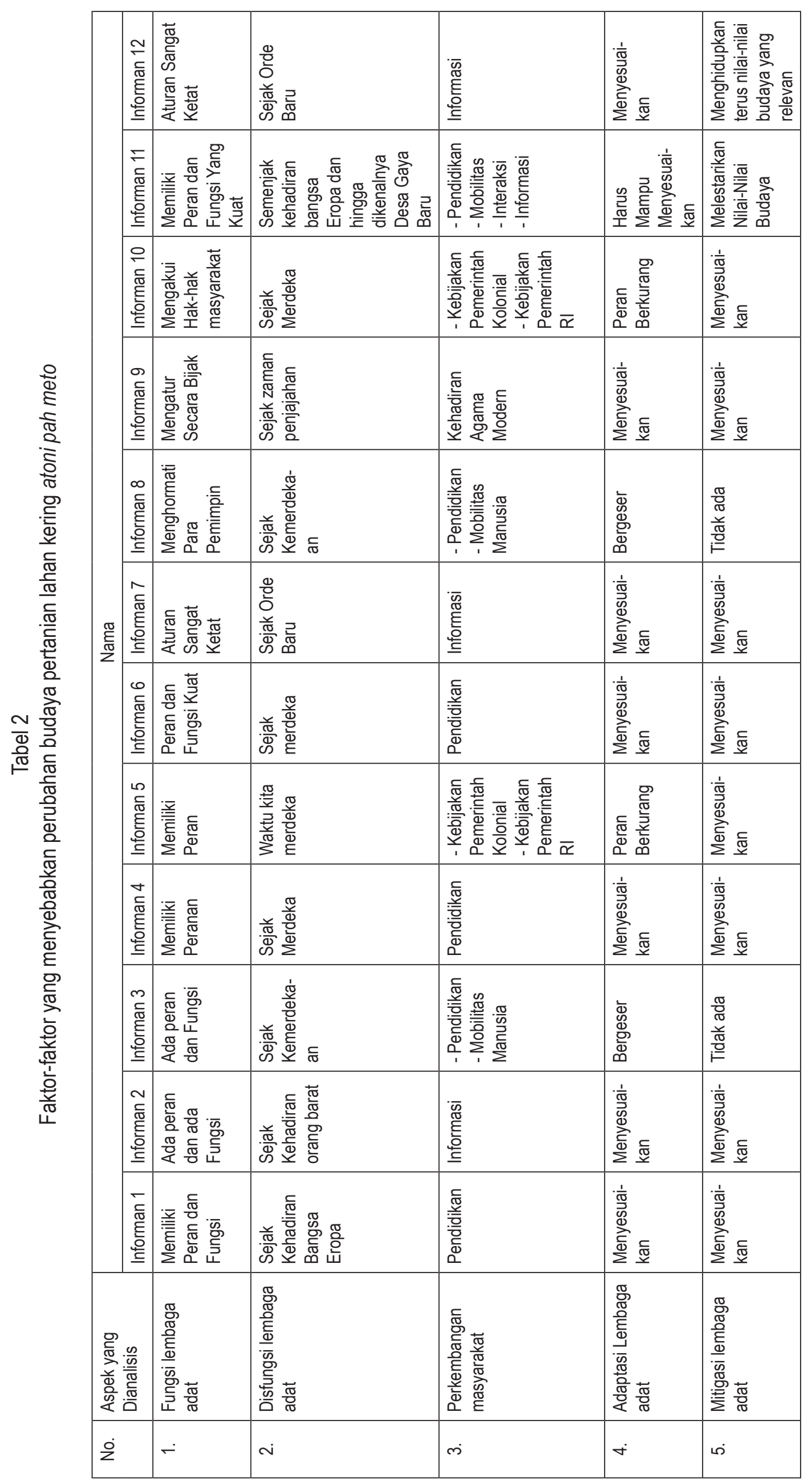




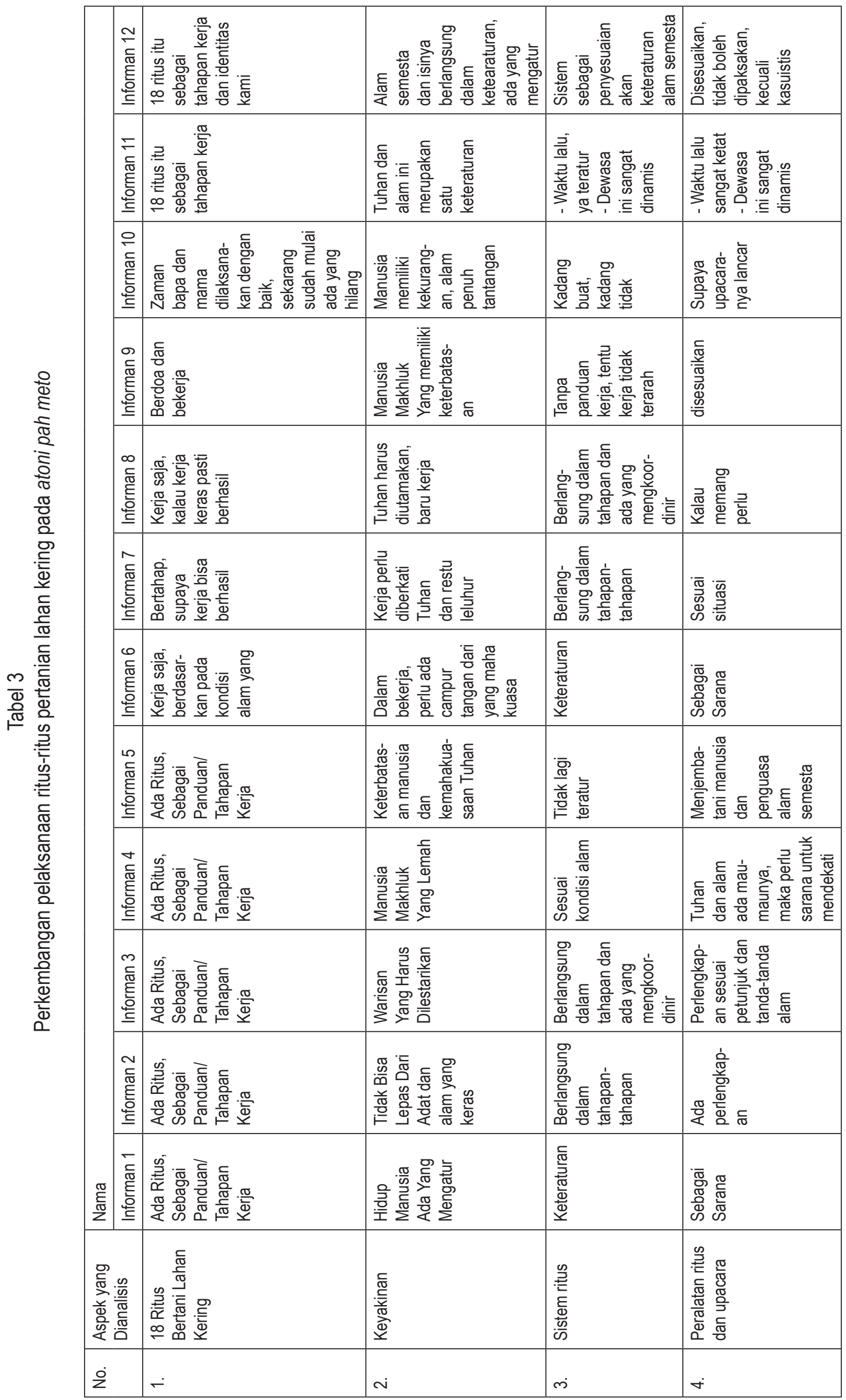




\begin{tabular}{|c|c|c|}
\hline 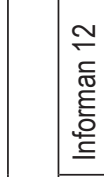 & 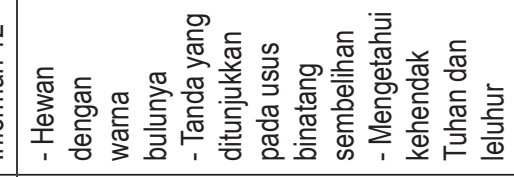 & 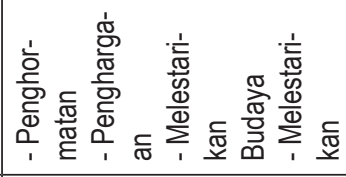 \\
\hline 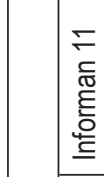 & 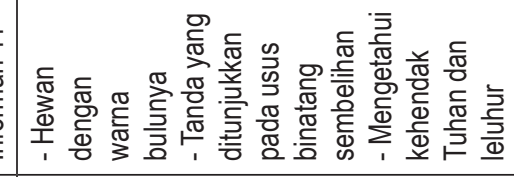 & 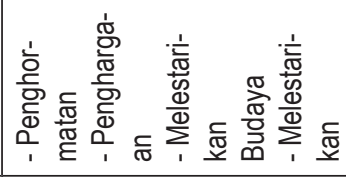 \\
\hline 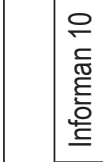 & 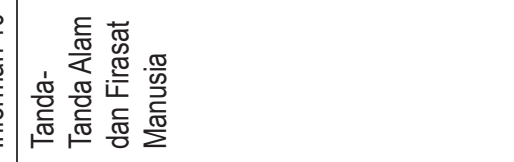 & 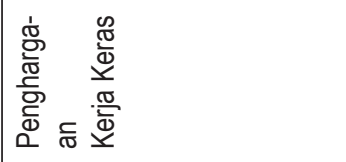 \\
\hline 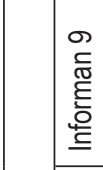 & 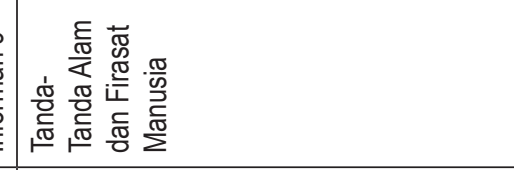 & 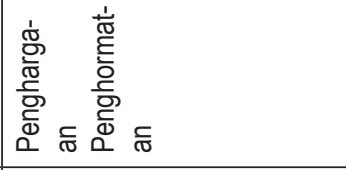 \\
\hline 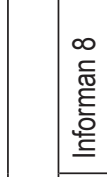 & 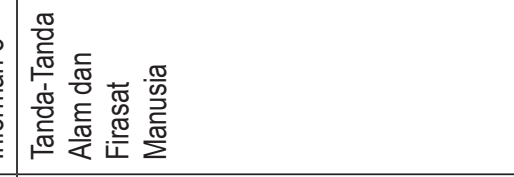 & 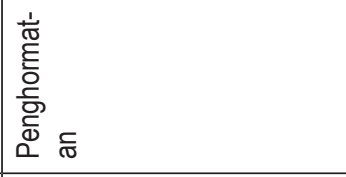 \\
\hline 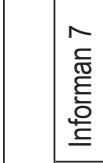 & 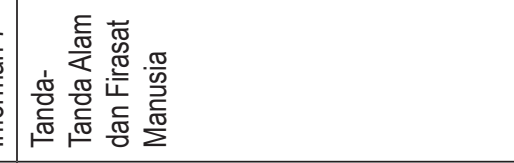 & 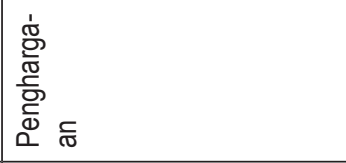 \\
\hline 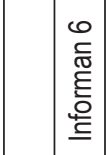 & 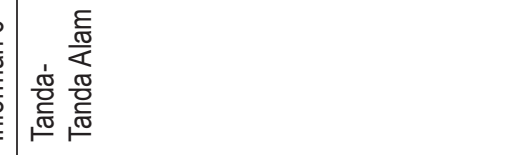 & 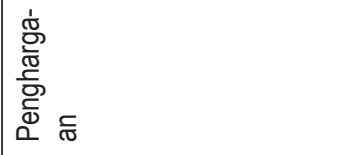 \\
\hline 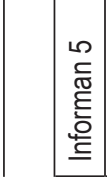 & 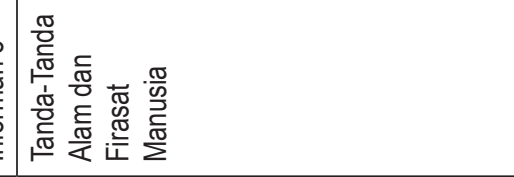 & 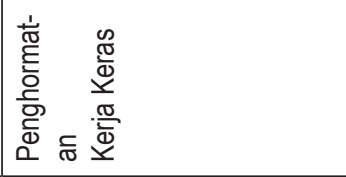 \\
\hline 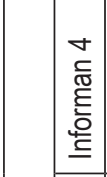 & 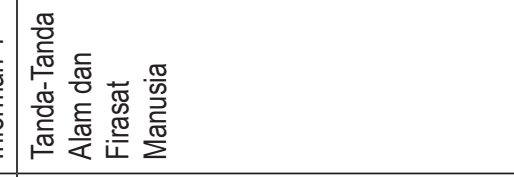 & 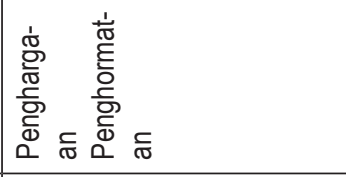 \\
\hline 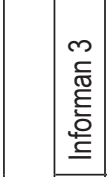 & 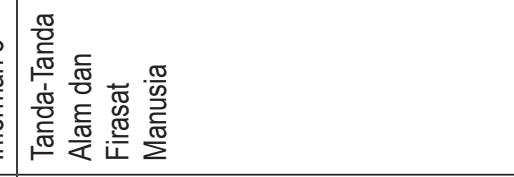 & 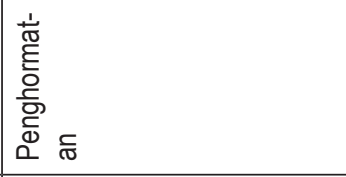 \\
\hline 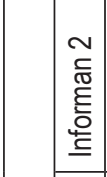 & 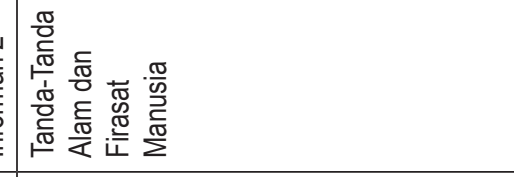 & 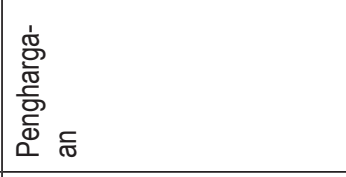 \\
\hline 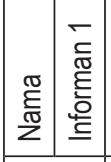 & 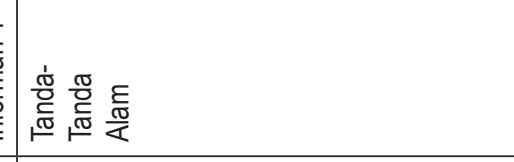 & 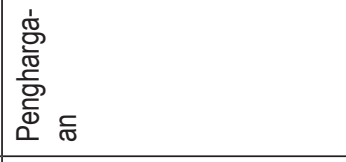 \\
\hline 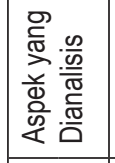 & $\begin{array}{l} \\
\overline{0} \\
\text { है } \\
\text { हक } \\
\end{array}$ & $\frac{\overline{\bar{w}}}{\overline{\bar{z}}}$ \\
\hline i் & is & ம \\
\hline
\end{tabular}




\begin{tabular}{|c|c|c|c|}
\hline \multirow{14}{*}{ 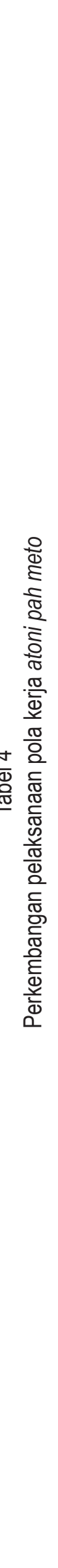 } & \multirow{14}{*}{ 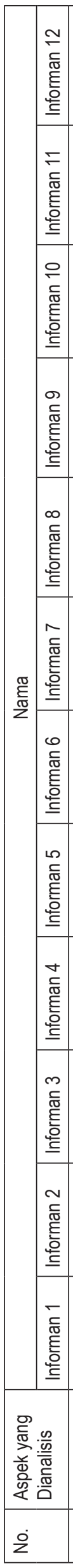 } & 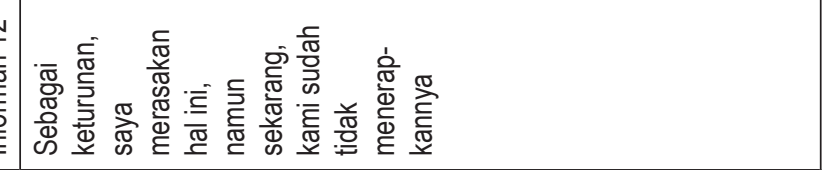 & 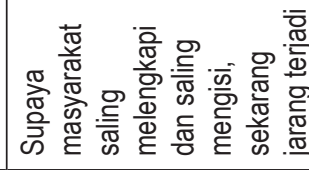 \\
\hline & & 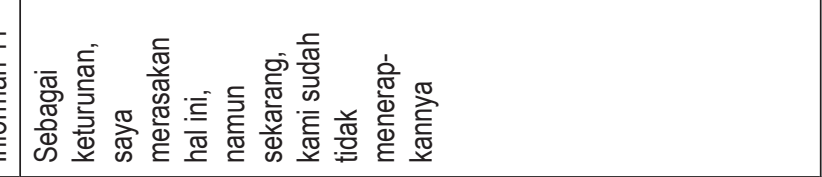 & 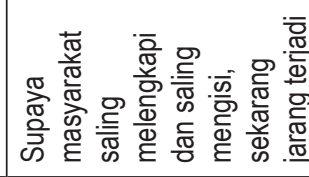 \\
\hline & & 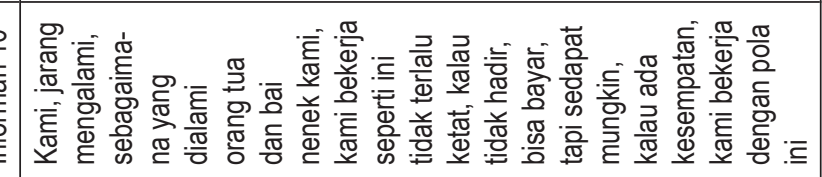 & 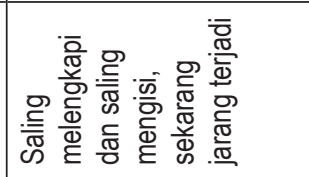 \\
\hline & & 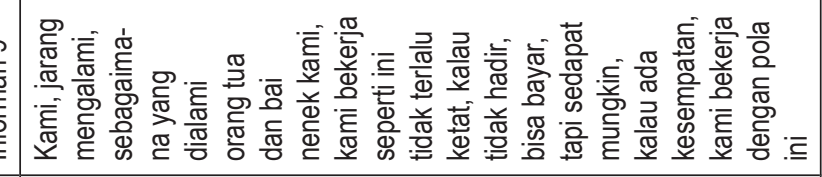 & 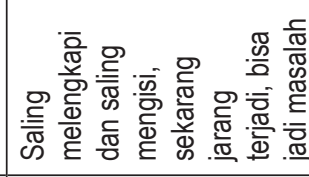 \\
\hline & & 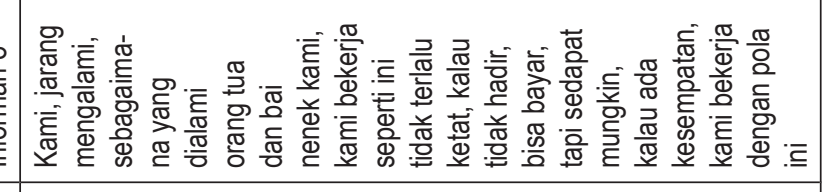 & 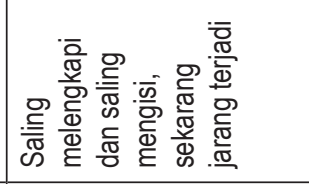 \\
\hline & & 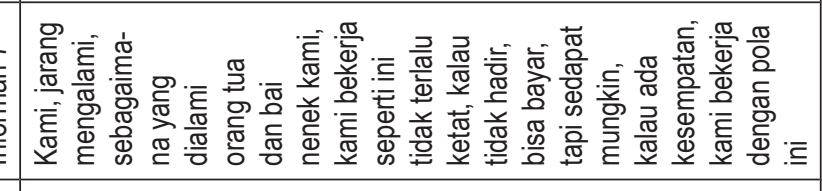 & 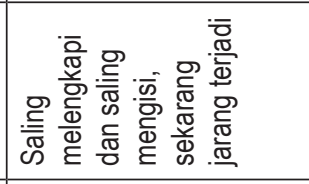 \\
\hline & & 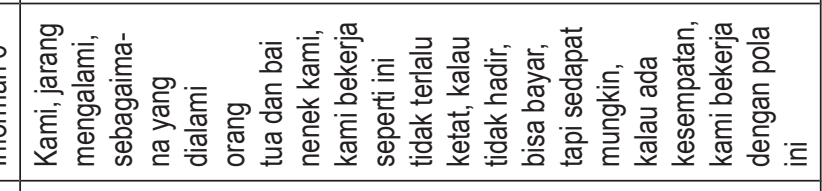 & 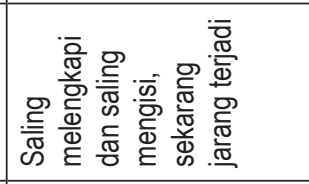 \\
\hline & & 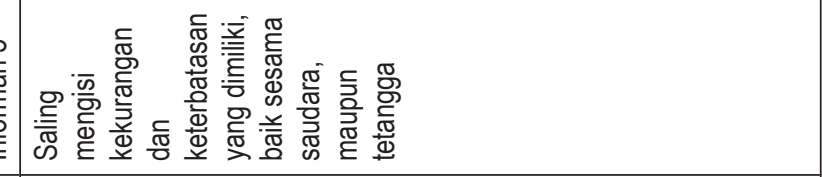 & 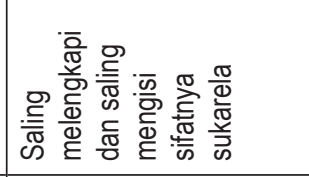 \\
\hline & & 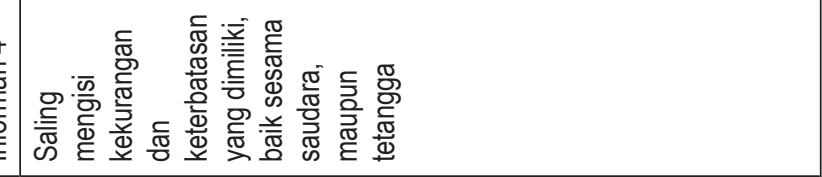 & 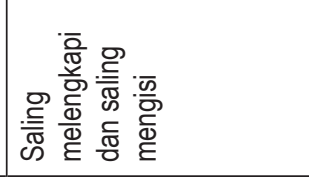 \\
\hline & & 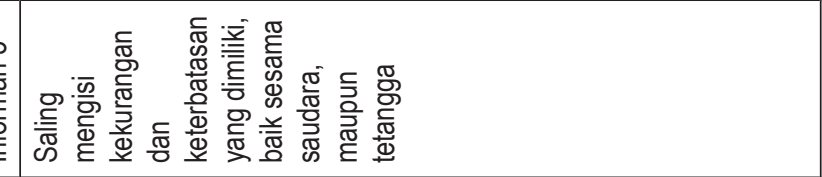 & 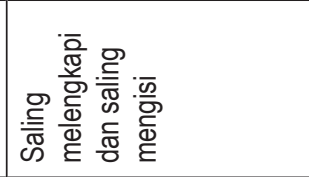 \\
\hline & & 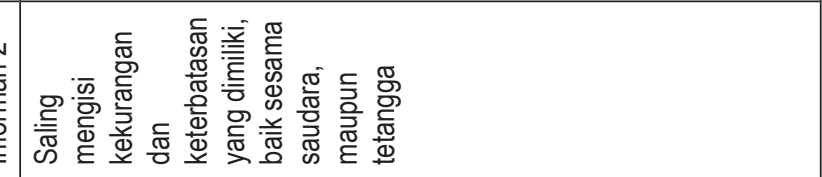 & 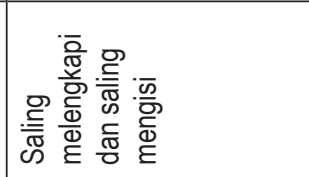 \\
\hline & & 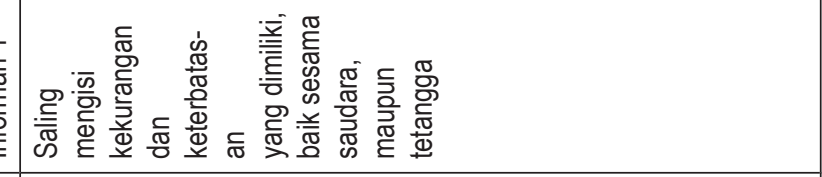 & 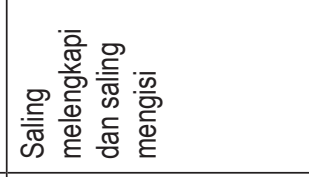 \\
\hline & & 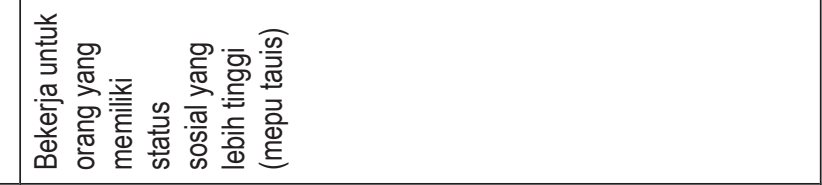 & 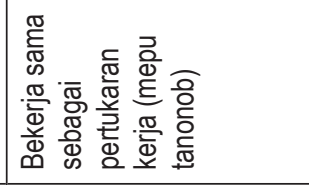 \\
\hline & & $\therefore$ & i \\
\hline
\end{tabular}




\begin{tabular}{|c|c|c|}
\hline 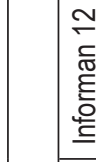 & & 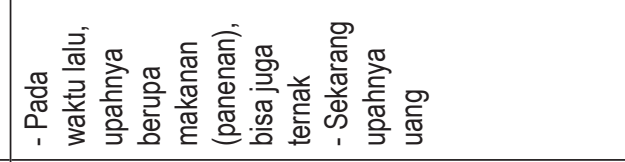 \\
\hline 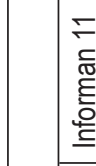 & & 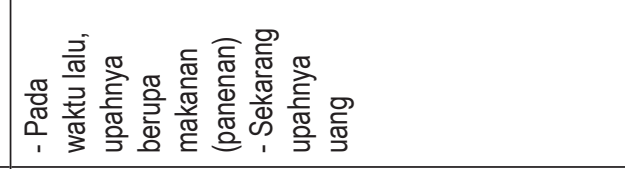 \\
\hline 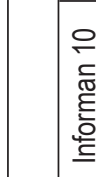 & 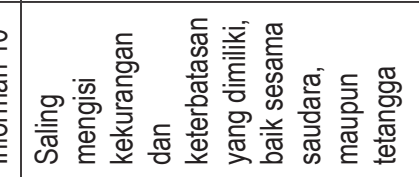 & 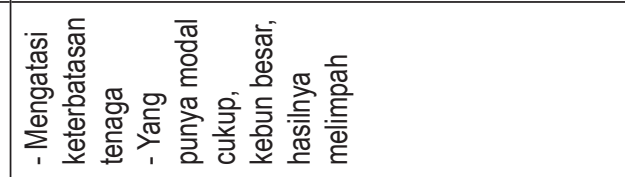 \\
\hline 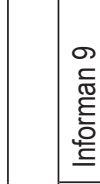 & 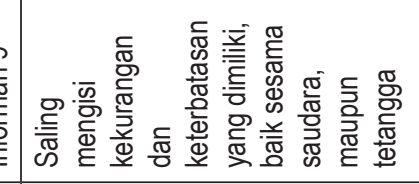 & 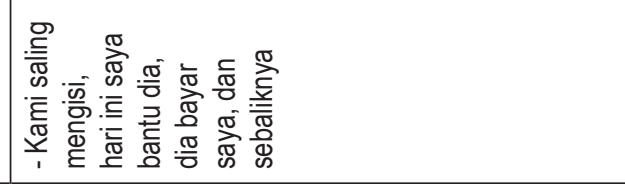 \\
\hline 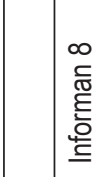 & 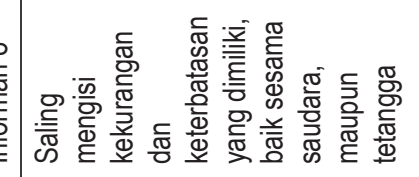 & 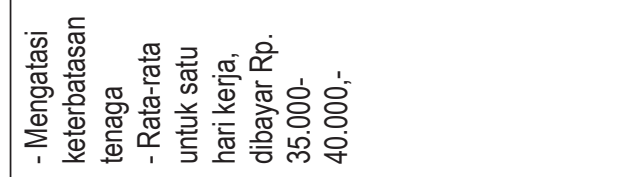 \\
\hline 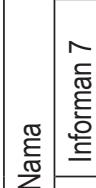 & 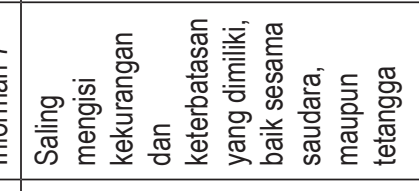 & 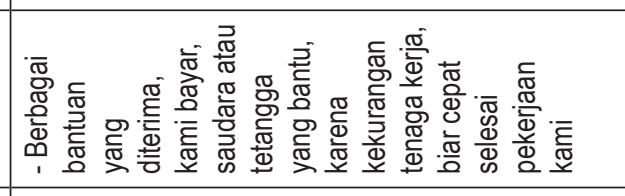 \\
\hline 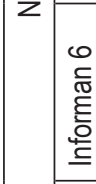 & 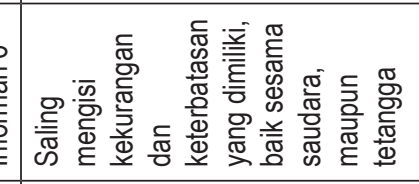 & 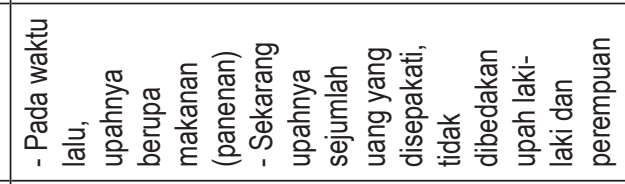 \\
\hline 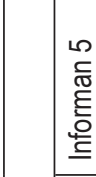 & 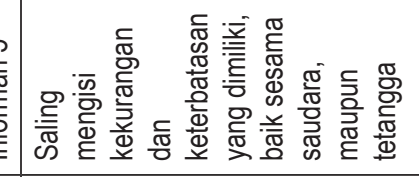 & 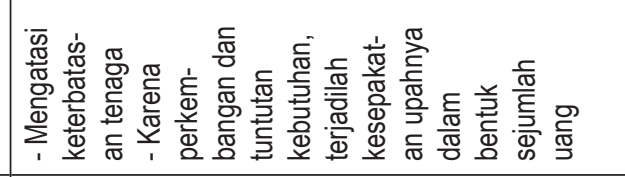 \\
\hline 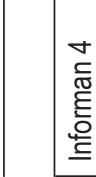 & 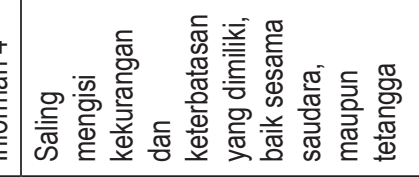 & 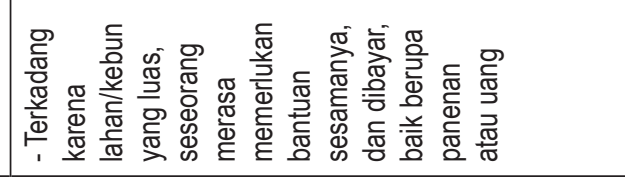 \\
\hline 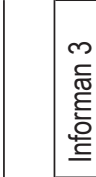 & 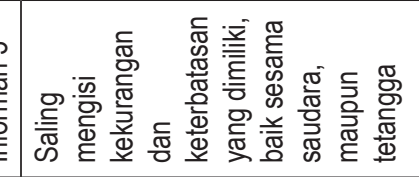 & 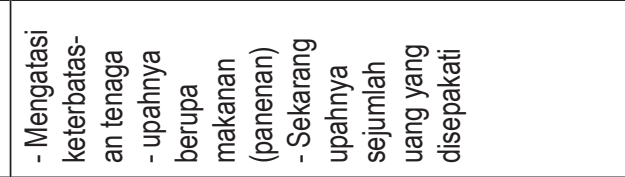 \\
\hline 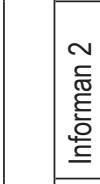 & 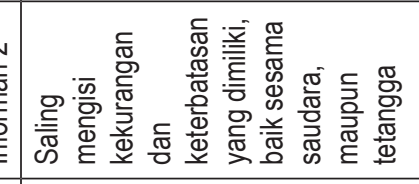 & 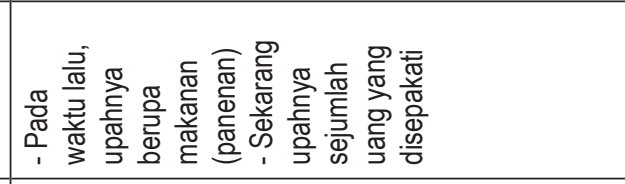 \\
\hline 竞 & 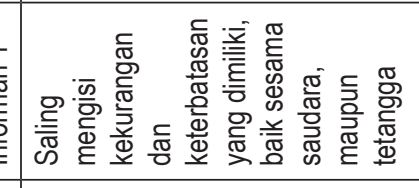 & 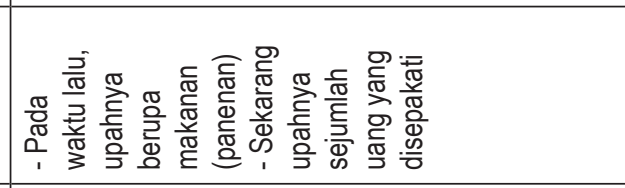 \\
\hline 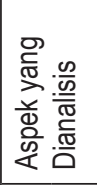 & 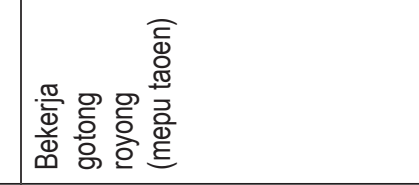 & 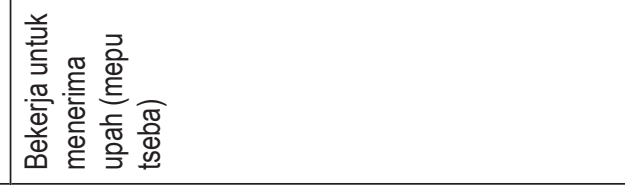 \\
\hline$\dot{z}$ & 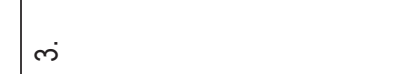 & $\dot{\forall}$ \\
\hline
\end{tabular}




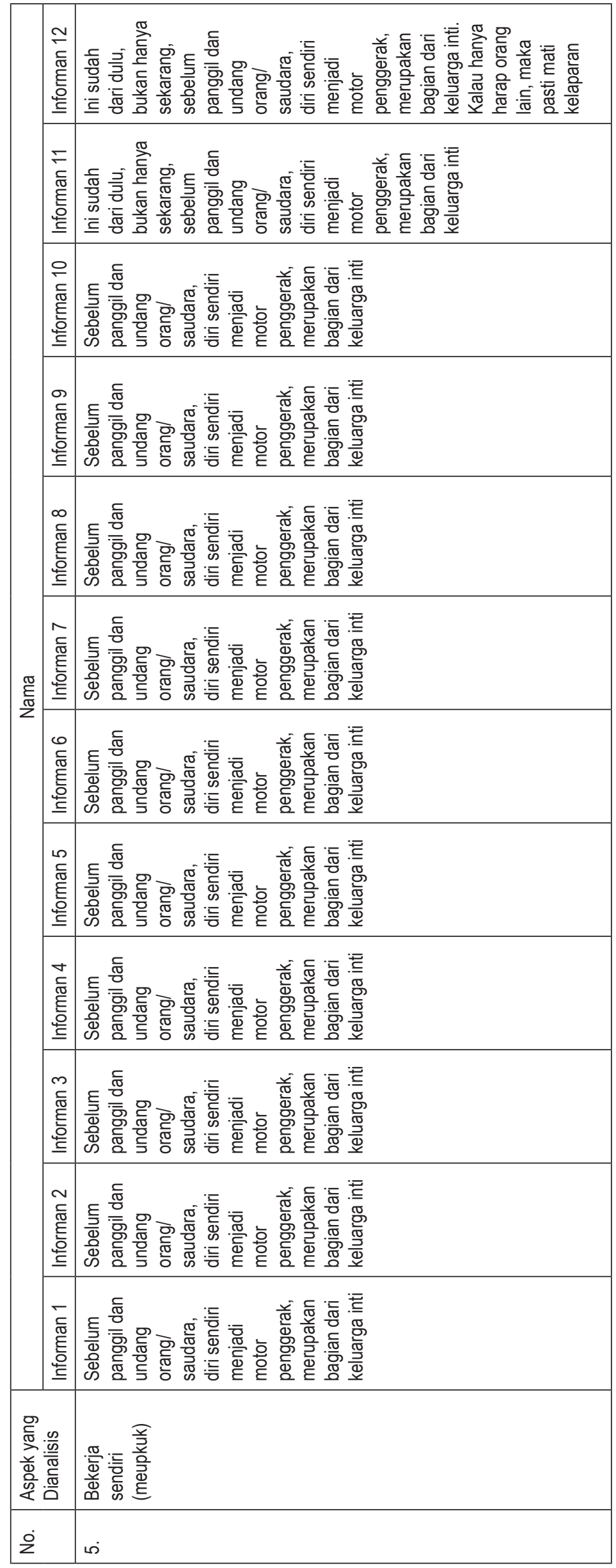




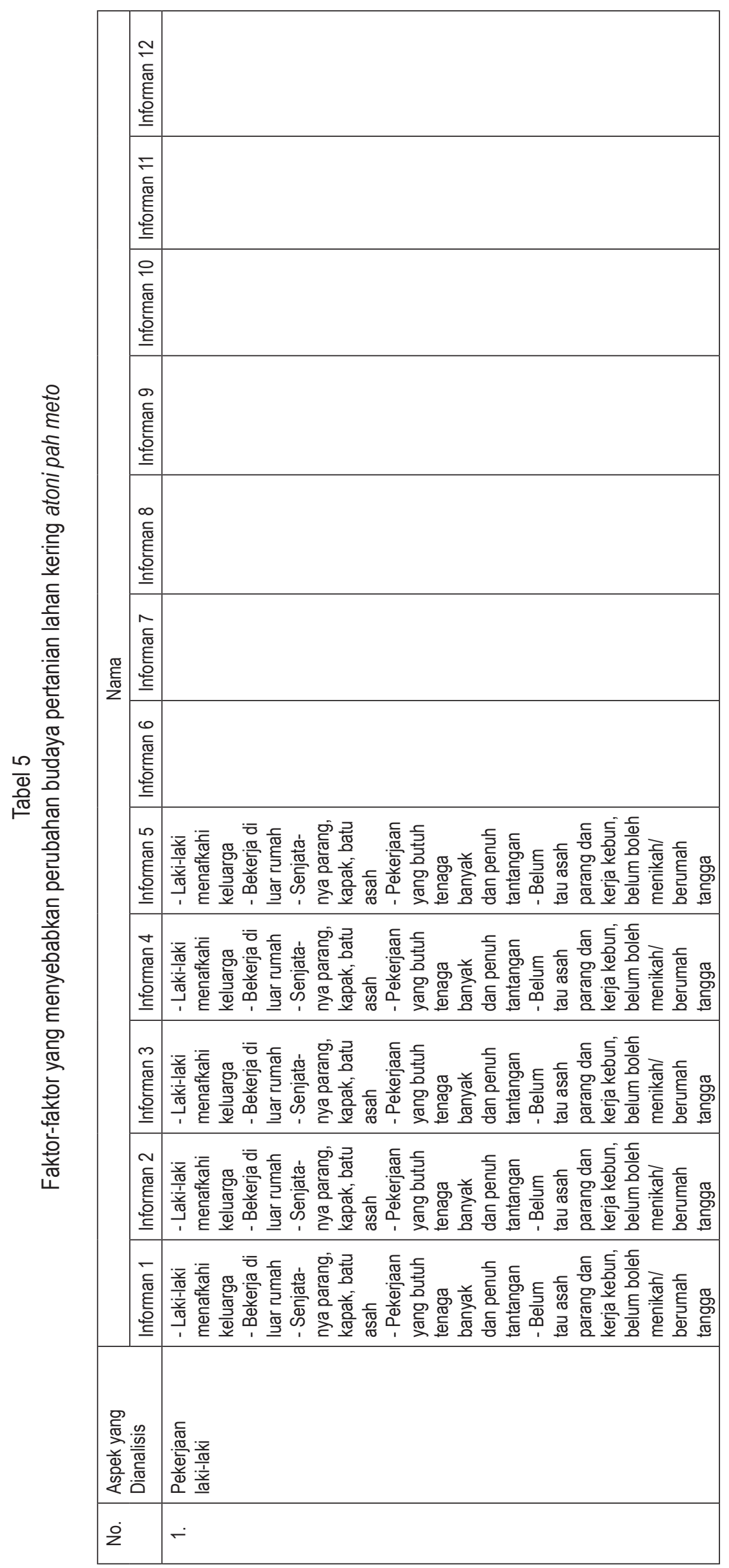




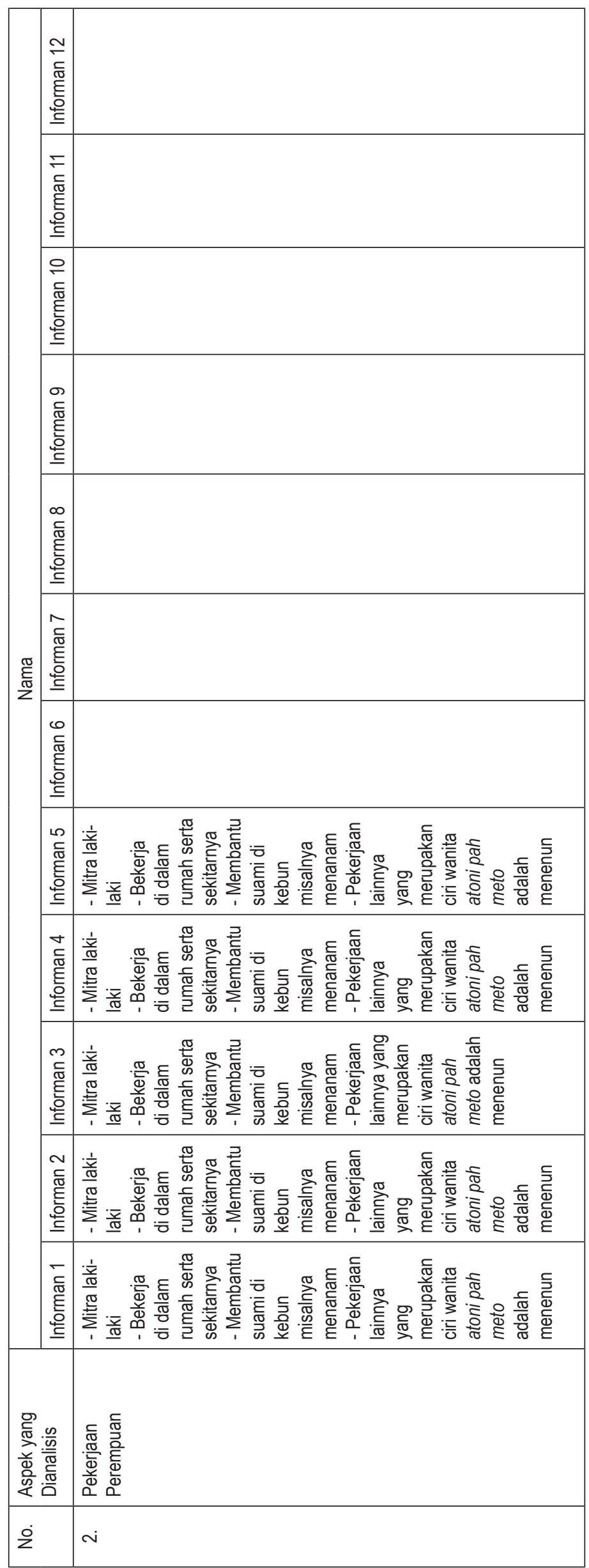

